\title{
The Invasive Species of Walhalla Area in Columbus, Ohio
}

\author{
Mohannad G. Al-Saghir \\ Department of Environmental and Plant Biology, Ohio University Zanesville, Zanesville, Ohio, USA \\ Email: al-saghi@ohio.edu
}

How to cite this paper: Al-Saghir, M.G. (2016) The Invasive Species of Walhalla Area in Columbus, Ohio. Open Journal ot Ecology, 6, 659-666.

http://dx.doi.org/10.4236/oje.2016.611061

Received: January 1, 2016

Accepted: September 27, 2016

Published: September 30, 2016

Copyright $\odot 2016$ by author and Scientific Research Publishing Inc. This work is licensed under the Creative Commons Attribution International License (CC BY 4.0).

http://creativecommons.org/licenses/by/4.0/ (c) (i) Open Access

\begin{abstract}
Invasive species are plants, animals, or pathogens that are non-native (or alien) to the ecosystem under consideration and whose introduction causes or is likely to cause harm. Invasive species can harm both the natural resources in an ecosystem as well as threaten human use of these resources. Walhalla is an urban wooded ravine area (10 acre area) in the middle of Columbus, Ohio. Many residents are actually actively planting new invasive species in a misguided attempt to prevent erosion on their property. Other properties are suffering from not-so-benign neglect, as the existing trees are slowly succumbing to insect infestation and rot (because of moisture trapped by ivy, etc.) and no new saplings are emerging to replace them (because of the thick ground cover). In both of these instances, it's proving to be difficult to convince the landowners that they're causing more harm than good-the local soil \& water conservation people are all too eager to reinforce the notion that the ground must be covered with a blanket of impenetrable invasive species in order to prevent erosion. The objectives of this study were to collect and identify the invasive species in Walhalla area in order to educate the residents about these species and its impact on their properties and gardens; moreover, using the findings of this project to develop a plan to remove these dangerous species. This survey has documented 18 invasive species in 18 families. Two notable invasive species were found in this area, Alliaria petiolata (M. Bieb.) Cavara \& Grande and Hedera helix L. (English Ivy). The found invasive species have an abundant growth in the studied area. The studied area has had no previous botanical collecting. Therefore, the area was in an urgent need to be inventoried and analyzed in order to identify and document its invasive species. Moreover, these identified species will be used for educational purposes for the residents of this area and well rounded plan is developed to remove these harmful species. This inventory represents a model for the other residential and agricultural areas in the state to follow, which will help overcome the negative impact and damage caused by the invasive species in these areas.
\end{abstract}




\section{Keywords}

Walhalla, Flora, Invasive Species, Inventory, Ohio

\section{Introduction}

Invasive species are plants, animals, or pathogens that are non-native (or alien) to the ecosystem under consideration and whose introduction causes or is likely to cause harm. Invasive species can harm both the natural resources in an ecosystem as well as threaten human use of these resources. An invasive species can be introduced to a new area via water resources, intentional and accidental releases of species, agricultural activities and other means [1].

Invasive species are capable of causing extinctions of native plants and animals, reducing biodiversity, competing with native organisms for limited resources, and altering habitats. This can result in huge economic impacts and fundamental disruptions of the ecosystems [1].

Walhalla is an urban wooded ravine area (10 acre area) in the middle of Columbus, Ohio. It is very close to I-71 (highway). It is part of the Olentangy watershed: the creek flowing through its empties into the Olentangy River north of the Ohio State University (OSU) Wetland lab. The area has residential properties with a variety of landscap. Many residents have removed (or never had established) invasive species such as English ivy, pachysandra, euonymus, honeysuckle, etc. from their properties (and the forest floor is recovering nicely there).

Unfortunately, many residents are actually actively planting new invasive species in a misguided attempt to prevent erosion on their property. Other properties are suffering from not-so-benign neglect, as the existing trees are slowly succumbing to insect infestation and rot (because of moisture trapped by ivy, etc.) and no new saplings are emerging to replace them (because of the thick ground cover). In both of these instances, it's proving to be difficult to convince the landowners that they're causing more harm than good-the local soil \& water conservation people are all too eager to reinforce the notion that the ground must be covered with a blanket of impenetrable invasive species in order to prevent erosion.

To counteract the conventional wisdom, a botanical specific survey is needed to specifically pin point these harmful invasive species. The objectives of this study were to collect and identify the invasive species in Walhalla area in order to educate the residents about these species and its impact on their properties and gardens; moreover, using the findings of this project to develop a plan to remove these dangerous species.

\section{Methodology}

\subsection{Study Site}

Walhalla is an urban wooded ravine area (5 mile area) in the middle of Columbus, 
Ohio. It is very close to I-71 (highway). It is part of the Olentangy watershed; the creek flowing through its empties into the Olentangy River north of the Ohio State University (OSU) Wetland lab. This area was chosen, because several home owners in the area had invited the author to do a botanical survey of their area as they were concerned about the rapid growth and damage of the invasive species grown in their properties. The initial assessment conducted by the author has concluded that a botanical specific survey is needed to specifically pin point these harmful invasive species.

\subsection{Plant Collection}

The studied area has three distinctive ecological communities: slope, ravine and riparian forest. Riparian was the most predominant community. Plant specimens were collected from all these communities in June and July 2012. The study was done in the herbarium of Ohio University-Zanesville.

Plants were identified and confirmed as invasive species using Braun (1961 and 1967) [2] [3], Flora of North America Editorial Committee (FNA; 1993) [4], Gleason and Cronquist (1991) [5], Holmgren (1998) [6] and Ohio Department of Natural Resources/Plant Invasive species list [7]. Species nomenclature follows Cooperrider et al. (2001) [8]. Family classification of seed plants follows Judd et al. (2002) [9].

\section{Results and Discussion}

This survey has documented 18 invasive species in 18 families (Table 1). Two notable invasive species were found in this area is Alliaria petiolata (M. Bieb.) Cavara \& Grande and Hedera helix L. (English Ivy). The found invasive species have an abundant growth in the studied area (Figure $1 \&$ Figure 2).

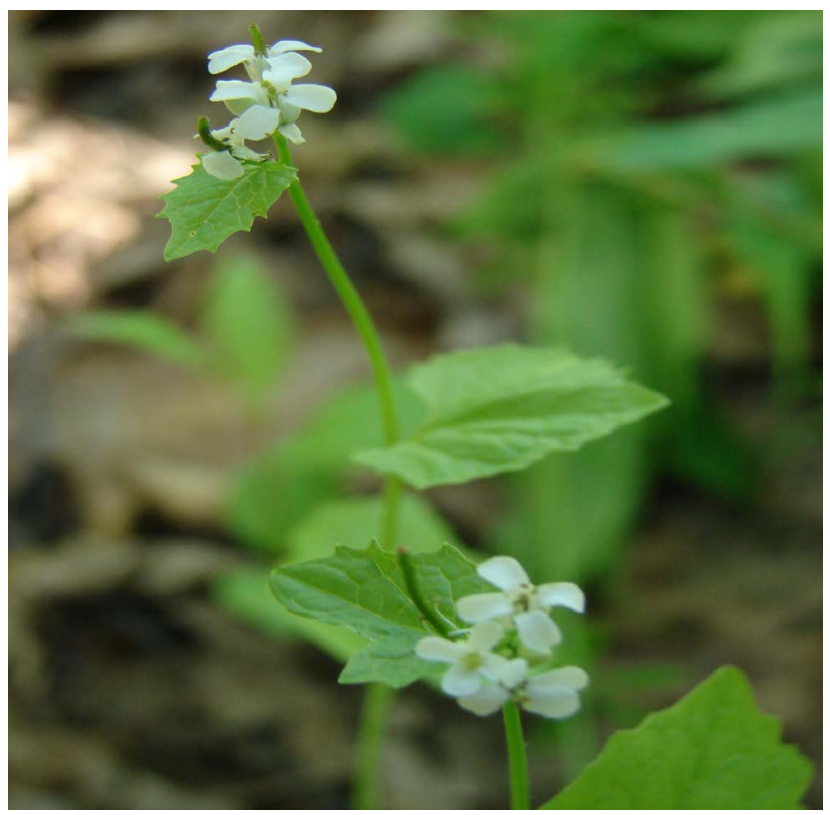

Figure 1. The abundant growth of the Alliaria petiolata (Garlic Mustard). 


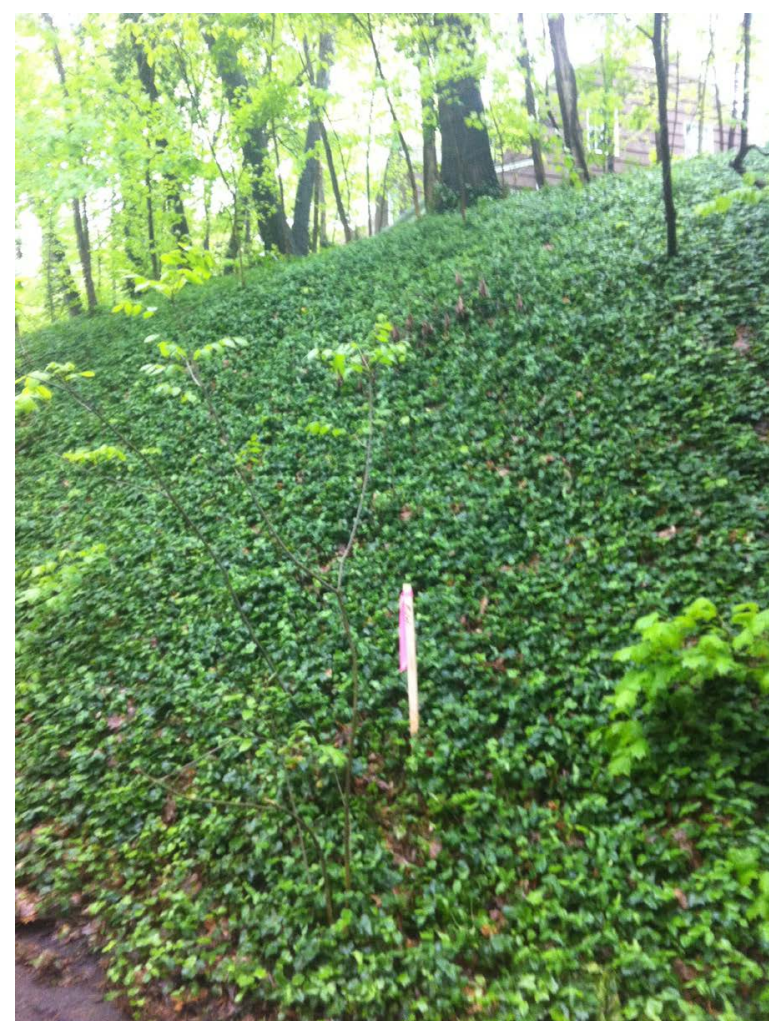

Figure 2. The abundant growth of the Hedera helix (English Ivy).

The 10-acre area consists of mostly secondary growth forest, a d ravine and a slope. The predominant issue concerning the area is the abundance of invasive species (Figure 1). They are taking over the forest floor and kill all the garden plants. Their damage is immense. The following paragraphs detail the key characteristics and the vegetation for each zone based on this inventory and field assessment made by the author.

1) Ravine

Characterized by steep slopes, dense shade, and well-drained soils with a thin layer organic soil layer. The ravine is a sensitive zone because of its significant sloping terrain. Erosion appears to be affecting its current condition. Adjacent land use is likely influencing local runoff. Increased volume and redirected flow are jeopardizing the ravine community because of the erosion of the organic soil layer and structural soils. Efforts to protect and enhance near off-site vegetation should be made for preventative purposes. Three invasive species were found (Table 1).

\section{2) Riparian}

The riparian forest is a dynamic environment. Conditions appear to fluctuate rapidly with weather events. Vegetation suitable for the zone should be capable of withstanding fluctuating water levels. 14 invasive species were found (Table 1).

3) Slope Face-North

Slope is characterized by significant slope, a mature overstory, and protected microclimate. One invasive species was found (Table 1). 
Table 1. Ohio Walhalla invasive species collection 2012.

\begin{tabular}{|c|c|c|c|c|c|}
\hline \multirow[b]{2}{*}{ Collection\# } & \multicolumn{5}{|c|}{ Plant Sample Information } \\
\hline & Species Name & Common Name & Family Name & $\begin{array}{l}\text { Collection } \\
\text { Date }\end{array}$ & Community Type \\
\hline W1 & $\begin{array}{l}\text { Euonymus fortunei } \\
\text { (Turcz.) Hand.-Maz. }\end{array}$ & Winter-creeper & Celasteraceae & 6-28-2012 & Riparian Forest \\
\hline W2 & $\begin{array}{c}\text { Impatiens capensis } \\
\text { Meerb. }\end{array}$ & $\begin{array}{c}\text { Orange } \\
\text { Touch-me-not/Jew } \\
\text { el-weed }\end{array}$ & Balsaminaceae & 6-28-2012 & Riparian Forest \\
\hline W3 & Circaea lutetiana L. & $\begin{array}{l}\text { Common } \\
\text { Enchanter's } \\
\text { Nightshade }\end{array}$ & Onagraceae & 6-28-2012 & Riparian Forest \\
\hline W4 & Hedera helix L. & English Ivy & Araliaceae & 6-28-2012 & Riparian Forest \\
\hline W5 & $\begin{array}{l}\text { Alliaria petiolata } \\
\text { (M. Bieb) } \\
\text { Cavara \& Grande }\end{array}$ & Garlic Mustard & Brassicaceae & 6-28-2012 & Slope \\
\hline W6 & Vitis vulpina $\mathrm{L}$. & Frost-grape & Vitaceae & $6-28-2012$ & Riparian Forest \\
\hline W7 & Elymus virginicus $\mathrm{L}$. & Virginia Wild Rye & Poaceae & 6-28-2012 & Riparian Forest \\
\hline W8 & $\begin{array}{l}\text { Penthorum } \\
\text { sedoides } \mathrm{L} .\end{array}$ & Ditch Stonecrop & Crassulaceae & 6-28-2012 & $\begin{array}{c}\text { Ravine, Opening } \\
\text { Dead Standing Trees }\end{array}$ \\
\hline W9 & $\begin{array}{c}\text { Polygonum } \\
\text { cespitosum Blume }\end{array}$ & $\begin{array}{l}\text { Oriental Lady's } \\
\text { Thumb }\end{array}$ & Polygonaceae & 6-28-2012 & $\begin{array}{c}\text { Ravine, Opening } \\
\text { Dead Standing Trees }\end{array}$ \\
\hline W10 & Carex frankii Kunth & Frank's Sedge & Cyperaceae & 6-28-2012 & $\begin{array}{c}\text { Ravine, Opening } \\
\text { Dead Standing Trees }\end{array}$ \\
\hline W11 & $\begin{array}{c}\text { Sanicula } \\
\text { canadensis L. }\end{array}$ & Canada Sanicle & Apiaceae & 7-20-2012 & Riparian Forest \\
\hline W12 & Viola striata Aiton & Creamy Violet & Violaceae & 7-20-2012 & $\begin{array}{c}\text { Opening in Riparian } \\
\text { Forest }\end{array}$ \\
\hline W13 & $\begin{array}{l}\text { Symphyotrichum } \\
\text { cordifolium (L.) } \\
\text { G.L. Nesom }\end{array}$ & $\begin{array}{l}\text { Common Blue } \\
\text { Heart-Leaved } \\
\text { Aster }\end{array}$ & Asteraceae & 7-20-2012 & $\begin{array}{c}\text { Opening in Riparian } \\
\text { Forest }\end{array}$ \\
\hline W14 & Prunella vulgaris $\mathrm{L}$. & Self-heal & Lamiaceae & $7-20-2012$ & Riparian Forest \\
\hline W15 & $\begin{array}{c}\text { Smilax glauca } \\
\text { Walter }\end{array}$ & Cat Greenbrier & Smilacaceae & 7-20-2012 & Riparian Forest \\
\hline W16 & $\begin{array}{l}\text { Pilea pulmila } \\
\text { (L.) A. Gray }\end{array}$ & $\begin{array}{l}\text { Canadian } \\
\text { Clearweed }\end{array}$ & Urticaceae & 7-20-2012 & Riparian Forest \\
\hline W17 & $\begin{array}{l}\text { Geum vernum (Raf.) } \\
\text { Torr. \& A. Gray }\end{array}$ & Spring Avens & Rosaceae & 7-20-2012 & Riparian Forest \\
\hline W18 & $\begin{array}{l}\text { Smilacina racemosa } \\
\text { (L.) Desf. }\end{array}$ & $\begin{array}{c}\text { False Solomon's } \\
\text { Seal }\end{array}$ & Asparagaceae & 7-20-2012 & Riparian Forest \\
\hline
\end{tabular}

\subsection{The Studied Invasive Species and Plan to Remove These Harmful Species}

This study was the first to be conducted in this area. This study has reported 18 invasive 
species. The two most notable and damaging invasive species were Alliaria petiolata (M. Bieb.) Cavara \& Grande. (Garlic Mustard) and Hedera helix L. (English Ivy). Garlic mustard is a biennial herb that grows from a taproot. Stems are erect and sparsely hairy and unbranched below the inflorescences. Garlic mustard often dominates forest under stories and outcompetes native species for light, moisture, and nutrients. It readily spreads into undisturbed forests and species-rich sites. Garlic mustard appears to alter habitat suitability for native birds, mammals, and amphibians, and it may affect the populations of these animals. Garlic mustard reduces foraging sites for deer and other large herbivores. Phytotoxic chemicals produced by garlic mustard may interfere with the growth of native plant species. Garlic mustard has no known natural enemies in North America [10] [11]. English Ivy is evergreen vine that can trail along the ground or grow veritcally up trees, fences, walls and hillsides. Most common type of growth lacks flowers and has dull green, lobed leaves with light veins that grow alternately along trailing or climbing stems. Leaf shape and size varies between varieties from deeply to shallowly lobed and from small, narrow leaves to large, broadly shaped leaves. Mature form of growth has shiny, unlobed leaves that grow in dense, whorl-like clusters and produce umbrella-like groups of small yellow-green flowers in the fall, followed by dark purple-black berries in the late winter or early spring. When ivy vines climb, small rootlets form that exude a glue-like substance to allow the vines to attach to almost any surface. Older vines can be tree-like and as much as five inches thick [12].

The management of invasive plant species in this area should be focused on those with the smallest populations, because they can be controlled easily before they spread farther, and complete elimination may be achievable within a few years. Elimination of other species populations would be more feasible than Alliaria petiolata and Hedera helix populations. In addition, all invasive plants should be removed from sensitive areas of the area. Removal of these invasive plants from these areas is a priority.

A combination of hand pulling, cutting, burning, and herbicide treatment can successfully control or eliminate garlic mustard. Garlic mustard can resprout after the removal of the aboveground biomass [13]. It is essential that an area be monitored for at least five years after the initial control efforts due to recruitment from the seed bank. Studies are being conducted to determine effective biological control agents, which include five European weevils and one flea beetle. If approved by the USDA, these biological control agents may become an option [14].

For English ivy here are some management recommendations that can be used for other species as well [15]:

\subsubsection{Mechanical Control}

Cutting: Cut climbing or trailing vines as close to the root collar as possible. This technique is feasible on small populations, as a pretreatment on large impenetrable sites, in areas where herbicide cannot be used, or if labor resources are not sufficient to adequately implement herbicidal control. Severed vines may continue to live on tree bark or other porous surfaces for several growing seasons. English ivy will resprout unless cut so frequently that its root stores are exhausted. 
Grubbing: This method is appropriate for small initial populations or environmentally sensitive areas where herbicides cannot be used. Using a pulaski or similar digging tool, remove the entire plant, including all roots and runners. Juvenile plants can be hand pulled depending on soil conditions and root development. Any portions of the root system not removed will potentially resprout.

Mulching: Mulching is an effective control on small infestations or in areas where herbicides cannot be used. Cover the entire infestation with several inches of mulch. This may include wood chips, grass clippings, hay or similar degradable plant material. Shredded or chipped wood may be the best option since hay and grass may potentially carry weed seeds. Covering the area with cardboard may improve the effectiveness and longevity of this method. The mulch should stay in place for at least two growing season and may need to be augmented several times.

\subsubsection{Herbicidal Control}

Stump Treatment: Use this method in areas where vines are established within or around non-target plants, or where vines have grown into the canopy.

Glyphosate: Cut the stem $5 \mathrm{~cm}$ ( 2 in) above ground level. Immediately apply a 25\% solution of glyphosate and water to the cross-section of the stem. This procedure is effective at low temperatures (as low as $40^{\circ} \mathrm{F}$ ) and may require a subsequent foliar application of glyphosate.

Triclopyr: Cut the stem $5 \mathrm{~cm}$ ( 2 in) above ground level. Immediately apply a $25 \%$ solution of triclopyr and water to the cross-section of the stem. This procedure remains effective at low temperatures $\left(<60^{\circ} \mathrm{F}\right)$ as long as the ground is not frozen. A subsequent foliar application may be necessary to control new seedlings.

Foliar Spray Method: Use this method to control large populations. It may be necessary to precede foliar applications with stump treatments to reduce the risk of damaging non-target species. Since English ivy is evergreen, the ideal time to spray is after surrounding vegetation has become dormant to avoid affecting non-target species.

Glyphosate: Apply a $4 \%$ solution of glyphosate and water plus $0.5 \%-1 \%$ non-ionic surfactant to thoroughly wet al foliage. Do not apply so heavily that herbicide will drip off leaves. Glyphosate is a non-selective systemic herbicide that may kill non-target partially sprayed plants. Ambient air temperature should be above $65^{\circ} \mathrm{F}$.

Triclopyr: If native grasses are intermingled with the ivy, triclopyr is preferred since it is selective to broadleaved plants. Apply a $2 \%$ solution of triclopyr and water to thoroughly wet an foliage. Do not apply so heavily that herbicide will drip off leaves. A $0.5 \%$ non-ionic surfactant is recommended in order to penetrate the leaf cuticle, and ambient air temperature should be above $65^{\circ} \mathrm{F}$.

\section{Conclusions}

The studied area has had no previous botanical collecting and was increasingly damaged by the growth of several invasive species. Therefore, the area was in an urgent need to be inventoried and analyzed in order to identify and document its invasive species. The study identified all the invasive species in the area and provides a manage- 
ment plan to remove these harmful species. Moreover, these identified species will be used for educational purposes for the residents of this area.

This inventory represents a model for the other residential and agricultural areas in the state to follow, which will help overcome the negative impact and damage caused by the invasive species in these areas.

\section{Acknowledgements}

The author is thankful for the Ohio University Zanesville for funding this project.

\section{References}

[1] Weber, E. (2003) Invasive Plant Species of the World: A Reference Guide to Environmental Weeds. CAB International North America.

[2] Braun, E.L. (1961) The Woody Plants of Ohio. The Ohio State University Press, Columbus, $\mathrm{OH}$.

[3] Braun, E.L. (1967) The Monocotyledoneae: Cat-Tails to Orchids. The Ohio State University Press, Columbus, $\mathrm{OH}$.

[4] Flora of North America Editorial Committee, Ed. (1993) Flora of North America North of Mexico, Vol. 2. Pteridophytes and Gymnosperms. Oxford University Press, Oxford and New York.

[5] Gleason, H.A. and Cronquist, A. (1991) Manual of Vascular Plants of Northeastern United States and Adjacent Canada. 2nd Edition, The New York Botanical Garden, Bronx, NY. http://dx.doi.org/10.21135/893273651.001

[6] Holmgren, N.H. (1998) Illustrated Companion to Gleason and Cronquist's Manual. The New York Botanical Garden, Bronx, NY.

[7] Ohio's Top Invasive Plants (2014). http://ohiodnr.gov/invasive-species/terrestrial-plants/list-of-ohios-top-invasive-plants

[8] Coopeerider, T.S., Cusick, A.W. and Kartesz, J.T., Eds. (2001) Seventh Catalog of the Vascular Plants of Ohio. The Ohio State University Press, Columbus, OH.

[9] Judd, W.S., Campbell, C.S., Kellogg, E.A. and Stevens, P.F. (2002) Plant Systematics: A Phylogenetic Approach. 2nd Edition, Sinauer Associates, Inc., Sunderland, MA.

[10] Nuzzo, V. (2000) Element Stewardship Abstract for Alliaria petiolata (Alliaria officinalis) Garlic Mustard. The Nature Conservancy. Arlington, Virginia. http://www.invasive.org/weedcd/pdfs/tncweeds/allipet.pdf

[11] Blossey, B., Nuzzo, V.A., Hinz, H.L. and Gerber, E. (2002) Garlic Mustard. In: Van Driesche, R., et al., Eds., Biological Control of Invasive Plants in the Eastern United States, USDA Forest Service Publication FHTET-2002-04, 413 p.

[12] Thomas, L. (1998) Topographic Alterations, Forest Structure, and Invasion by English Ivy (Hedera helix L.) in the Rock Creek Floodplain, Washington, D.C. Natural-Areas-Journal, 18, 164-168.

[13] Wisconsin Department of Natural Resources (2004). http://dnr.wi.gov

[14] Driesche, V.R. (2002) Biological Control of Invasive Plants in the Eastern United States, USDA Forest Service Publication FHTET-2002-04, 413 p.

[15] Southeast Exotic Pest Plant Council (2003) Southeast Exotic Pest Plant Council Invasive Plant Manual. The Bugwood Network-The University of Georgia. 
Submit or recommend next manuscript to SCIRP and we will provide best service for you:

Accepting pre-submission inquiries through Email, Facebook, LinkedIn, Twitter, etc.

A wide selection of journals (inclusive of 9 subjects, more than 200 journals)

Providing 24-hour high-quality service

User-friendly online submission system

Fair and swift peer-review system

Efficient typesetting and proofreading procedure

Display of the result of downloads and visits, as well as the number of cited articles

Maximum dissemination of your research work

Submit your manuscript at: http://papersubmission.scirp.org/

Or contact oje@scirp.org 